\title{
Isolation and Characterization of Potential Cellulose Degrading Bacteria from Sheep Rumen
}

\author{
Daba Gudeta Guder $(\mathbb{D}$ and M.S.R. Krishna* \\ Department of Biotechnology, KLEF, Guntur - 522 502, Andhra Pradesh, India.
}

\begin{abstract}
In the present study, cellulose degrading bacteria was isolated from sheep rumen. Screening of cellulose degrading bacteria was carried out based on CMC (carboxyl methyl Cellulose) hydrolytic test which was seen as clear zone around colony as well as whatsman filter paper degradation test. Twenty bacterial isolates with clearance zone diameter of $\geq 10 \mathrm{~mm}$ on CMC agar were screened out for filter paper degradation test. Out of twenty isolates, only eight were able to digest filter paper and subjected to cellulase enzyme assay, microbiological analysis and molecular characterization. Cellulase enzyme was extracted from each isolate and enzyme activity assay was performed based on 3-5, dinitro- salcylic acid (DNS) method. Enzyme activity ranged from $0.225 \mathrm{u} / \mathrm{ml}$ to $1.652 \mathrm{u} / \mathrm{ml}$ in which maximum result was obtained in bacterial isolate labelled as KLCD08. Bacteriological study of the isolates showed that five isolates (KLCD04, KLCD012, KLCD15, KLCD18, KLCD19) belong to Bacillus species, two isolates (KLCD01, KLCD09.) Bacteriodes species and one isolate (KLCD08) Enterobacter pecies. Molecular characterization was applied to the isolate with greater cellulolytic activity (KLCD08) based on 16srRNA gene sequencing. According to phylogenetic analysis made by the use of EZBlocloud database, the isolate showed $\mathbf{9 9 . 8 4} \%$ homology with Enterobacter cloacae subsp. Dissolvens. The sequence was deposited to NCBI GenBank with accession number of MN120893. The identified bacteria could be used for large scale production of cellulase enzyme through bio-processing technology. It can also be formulated as probiotics in animal nutrition.
\end{abstract}

Keywords: Sheep rumen, Cellulose degrading bacteria, cellulase, CMC, 16srRNA.

\footnotetext{
*Correspondence: msrkrishna81@gmail.com

(Received: 03 June 2019; accepted: 10 July 2019)

Citation: Daba Gudeta Guder and M.S.R. Krishna, Isolation and Characterization of Potential Cellulose Degrading Bacteria from Sheep Rumen, J Pure Appl Microbiol., 2019; 13(3):1831-1839. https://doi.org/10.22207/JPAM.13.3.60

(c) The Author(s) 2019. Open Access. This article is distributed under the terms of the Creative Commons Attribution 4.0 International License which permits unrestricted use, sharing, distribution, and reproduction in any medium, provided you give appropriate credit to the original author(s) and the source, provide a link to the Creative Commons license, and indicate if changes were made.
} 


\section{INTRODUCTION}

Cellulose is the most abundant organic compound present on the earth. It is polymer of large number of glucose units bound by $\beta-1$, 4-glycosidic linkages. Each cellulose molecule contains as much as 10,000 glucose units. The degree of polymerization varies depending on the source of cellulose. The main source of cellulose is plant tissue in which it presents as a major component of cell wall ${ }^{1,2}$. Because of its strong glycosidic bond, cellulose is resistant to physical decomposition. Cellulose can only be degraded by an enzyme called cellulase which is naturally produced by some microorganisms like bacteria and fungi ${ }^{3}$.

Since many animals use plants as source of feed, gut cellulolytic microorganisms digest cellulose and convert it in to simple sugar that can be used as source of energy both for host animal and the microbes ${ }^{4,5}$. Bacteria is dominant cellulolytic microorganism in the gut of herbivores and other plant feeding organisms including insects. Cellulose degrading bacteria can be found in different areas including in gut of termites, rumen of ruminants, large intestine of equines and in organic waste materials ${ }^{6}$. Many reports showed that rumen is the main source of cellulose degrading bacteria because enzymatic and mechanical digestion of plant materials takes place in it ${ }^{7}$. In cattle potential cellulolytic bacteria include Bacteroides succinogenes, Clostridium, Trichonympha, Actinomycetes, Butyrivibriofibrisolvens, Ruminococcusalbus, and Methanobrevibacterruminantium ${ }^{8}$.

Cellulose degrading bacteria can be isolated for commercial production of cellulase enzyme in which the enzyme is extracted by the use of bio-processing technology ${ }^{9}$. However, cellulolytic potential of cellulose degrading bacteria varies depending on its species as well as nutritional behaviour of the host. Animals in which feeding habit purely depend on roughage materials, like grass and hay would have more potential cellulolytic bacteria than those depending on concentrate feeds ${ }^{10,11}$. Similarly enzymatic activity of cellulase enzyme depends on cellulolytic potential of the bacteria. Hence, isolation and identification of potential cellulose degrading bacteria is crucial for effective production of commercial Cellulase enzyme.
There is huge demand for cellulase enzyme in many industries like textile and paper production factories. In addition, cellulolytic organisms can be used as probiotics in animal nutrition to enhance digestion and increase growth and productivity of domestic animals ${ }^{12}$. The present study is to isolate and characterize potential cellulose degrading bacteria from sheep rumen.

\section{MATERIALS AND METHODS}

\section{Sample collection and preparation}

Rumen fluid was collected from sheep at local slaughterhouse in vaddeswaram, Guntur district, India. $5 \mathrm{ml}$ of rumen fluid was directly aspirated from rumen using 20gaugesyringe immediately following bleeding in the slaughtering process. The sample was used for further screening.

\section{Screening of Cellulolytic bacteria by use of CMC agar}

Screening of cellulose degrading bacteria on CMC (Carboxyl Methylcellulose) agar was done based on the standard protocol ${ }^{13}$. CMC agar, in which cellulose is used as energy, was prepared from cellulose $2 \mathrm{~g}, \mathrm{MgSO}_{4} 0.25 \mathrm{~g}$, agar $15 \mathrm{~g}$, $\mathrm{KH}_{2} \mathrm{PO}_{4} 0.5 \mathrm{~g}$, gelatin $2 \mathrm{~g}$ and Congo-Red $0.2 \mathrm{~g}$ in $1 \mathrm{~L}$ of distilled water at $\mathrm{pH} 7 \pm 2$. The solution was autoclaved to prepare sterile media. The sample was serially diluted in sterile saline water to form dilution of $10^{-1}$ to $10^{-6}$ in test tubes. Culturing was done by spreading $0.5 \mathrm{ml}$ of fluid on separate plates containing CMC agar from each serially diluted solution. The culture was incubated at $37^{\circ} \mathrm{C}$ for 5 days. The bacterial colony showing zone of clearance on $\mathrm{CMC}$ was considered as cellulose degrading bacteria. Hydrolysis of CMC and diameter of clear zone was used detect cellulolytic activity. Hydrolytic value of cellulose degrading bacteria was expressed as the ratio of clear zone diameter to clear zone diameter. Numerical value is obtained by dividing clear zone diameter by colony diameter ${ }^{14}$.

\section{Filter paper degradation test}

Bacterial colony showing greater zone of clearance on CMC were isolated and subjected to filter paper degradation test to confirm cellulolytic effect. The Isolates were separately cultured in basal salt media containing whatsman filter paper $^{15}$. Ten milliliters of sterile basal salt media was added to $20 \mathrm{ml}$ test tube. The media was 
inoculated with selected bacterial isolates showing positive test on $\mathrm{CMC}$ media. Whatsman filter paper ( 0.5 gram) was placed in each test tube. The tubes were placed in shaking incubator at $37^{\circ} \mathrm{C}$ for 10 days. This was to observe decomposition of filter paper in the medium by cellulolytic bacteria ${ }^{16}$. Only isolates showing positive result of cellulose degrading activity both on filter paper and CMC media were screened out and sub-cultured on separate plates containing nutrient media and maintained for further analysis.

\section{Cellulase enzyme Production and purification Extraction of crude cellulase}

Selected bacterial isolates with positive cellullolytic effect confirmed based on CMC hydrolysis and filter paper degradation were cultured in $\mathrm{CMC}$ broth for 24 hours at $37^{\circ} \mathrm{C}$. The culture was transferred to centrifuge tube and centrifuged at $14000 \mathrm{rpm}$ for 10 minutes at $4^{\circ} \mathrm{C}$. The supernatant was collected as source of crude Cellulase enzyme solution ${ }^{18}$.

\section{Purification of Cellulase enzyme}

The purification process of cellulase enzyme started with precipitation with ammonium sulfate. In this step, crude enzyme was mixed with ammonium sulfate powder until $80 \%$ saturation was obtained. The mixture was kept overnight at $4^{\circ} \mathrm{C}$ in magnetic stirrer and finally centrifuge to collect pellet. The pellet was dissolved with $50 \mathrm{mM}$ of sodium phosphate buffer at $7 \mathrm{pH}$ and dialyzed against phosphate buffer ${ }^{19}$. The dialyzed enzyme was maintained in $-20^{\circ} \mathrm{C}$ as partially purified protein sample.

\section{Cellulase Enzyme activity Assay}

Cellulase enzyme activity was determined by measuring the amount of reducing sugar produced by enzyme from CMC. The enzyme activity was determined according to the DNS (3, 5-dinitrosalicylic acid) assay methods which is recommended by the International Union of Pure and Applied Chemistry (IUPAC) commission on biotechnology. CMCase activity was determined by incubating $0.5 \mathrm{~mL}$ of supernatant with 0.5 $\mathrm{mL}$ of $2 \%$ amorphous cellulose in $0.05 \mathrm{~m}$ sodium citrate buffer ( $\mathrm{pH} \mathrm{4.8)}$ ) at 50 for $30 \mathrm{~min}$. After incubation for an hour at $50^{\circ} \mathrm{C}$, the reaction was terminated by adding $3 \mathrm{~mL}$ of 3, 5-dinitrosalicylic acid (DNS) reagent to $1 \mathrm{~mL}$ of reaction mixture. In these tests, reducing sugars were estimated spectrophotometrically with 3, 5-dinitrosalicylic acid using glucose as standards. The enzymatic activity of total CMCasewas defined in international units (IU). One unit of enzymatic activity is defined as the amount of enzyme that releases $1 \mu \mathrm{mol}$ reducing sugars (measured as glucose) per minute per $\mathrm{ml}^{21}$.

Cellulase enzyme activity assay calculated according to IUPAC shown in equation below.

Enzyme activity $(U / m l)=\frac{(E)(V f)}{(t)(\varepsilon)(V s)}$

Where,

$\mathrm{E}=$ Absorbance at $560 \mathrm{~nm}$

$\mathrm{V} f=$ Final volume including DNS

Vs $=$ Volume of enzyme

$\mathrm{t}=$ Incubation time

$\mathrm{d}=$ enzyme dilution

$\varepsilon=$ extinction coefficient

Morphological and biochemical characterization of isolates

Selected bacterial Colony with better cellulolytic activity were separately cultured on general media for morphological and biochemical analysis. Gram staining technique was used to characterize shape and gram-characteristic of selected isolate. Basic biochemical tests including Indole test, Methyl-Red test, Catalase test, oxidation reduction test, motility test, fermentation VP test and citrate utilization test was also employed to identify bacterial at genus level $^{22}$. The result of biochemical test was analyzed using ABIS online data base (www.tg1916.net/ bacteria_logare_desktop.html) to identify the bacteria.

Estimation of molecular weight of cellulase enzyme

SDS-PAGE was carried for ammonium sulphate precipitated and dialyzed enzyme sample to determine molecular weight of the enzyme based on standard procedure ${ }^{20}$. Albumin ( $\left.66 \mathrm{kDa}\right)$, ovalbumin (45 kDa), carbonic anhydrase(30 kDa), trypsin inhibitor (20.1 kDa) and $\alpha$-lactalbumin (14.4 kDa) were used as markers to estimate molecular mass of Cellulase enzyme.

16srRNA analysis and molecular characterization potential cellulolytic bacteria

Isolate with better cellulose degrading capability based on both hydrolytic value on CMC and enzymatic activity test was selected for molecular characterization based on 16srRNA 
gene sequencing. The selected isolate was characterized by 16 SrRNA sequencing at National Center for Microbial Resources (NCMR). Universal primers (F27:5'-AGAGTTTGATCCTGGCTCA-3' and R1492:5'-TACGGTTACCTTGTTACGACTT-3') were used for amplification of DNA fragments containing 16 srRNA gene ${ }^{24}$. The 16 srRNA gene sequence homology analysis of selected isolate was generated using EzBioCloud Database.

\section{RESULT AND DISCUSSION}

Screening of Cellulolytic bacteria by use of CMC agar

Cellulose degrading bacteria can produce cellulase enzyme that can hydrolyze cellulose in to simple sugar to use as source of energy. Bacterial colony producing cellulase enzyme showed hydrolytic effect which was seen as whitish clear zone with circular shape on CMC media surrounding bacterial colony. The diameter of clear zone indicates the cellullolytic capability of enzyme produced by cellulose degrading bacteria. In the present study, bacterial colonies which developed within specified incubation period with acceptable clear zone diameter were selected to have CMCase activity. Delayed growth with undetectable clear zone was not considered in the study. Based on CMC hydrolysis, only 20 isolates with clearance zone diameter of $>10 \mathrm{~mm}$ were considered as significant. The isolates were labeled as KLCD01, KLCD02, KLCD03, KLCD04, KLCD05, KLCD06, KLCD07, KLCD08, KLCD09, KLCD10, KLCD11, KLCD12, KLCD13, KLCD14, KLCD15, KLCD16, KLCD17, KLCD18, KLCD19 and KLCD20. The isolates were subculture separately for further analysis. CMC agar was used as selective media to allow the growth of bacteria which can digest cellulose since it contains only cellulose as source of energy. YanLing L. et al used CMC agar to screen and isolate cellulose degrading bacteria and selected bacterial colony with measurable diameter of clear zone ${ }^{24}$. Filter paper degradation test

Among the twenty isolates eight isolates were able to degrade filter paper which was seen as decomposed filter paper forming a turbid solution in the test tube Among the twenty isolates

Table 1. Clearance zone diameter and enzyme hydrolytic value of Cellulose degrading bacteria

\begin{tabular}{|c|c|c|c|c|c|}
\hline No. & Isolate ID & $\begin{array}{l}\text { Diameter of } \\
\text { clear Zone } \\
(\mathrm{mm})\end{array}$ & $\begin{array}{l}\text { Colony } \\
\text { diameter } \\
(\mathrm{mm})\end{array}$ & $\begin{array}{c}\text { Hydrolytic } \\
\text { value }\end{array}$ & $\begin{array}{l}\text { Filter paper } \\
\text { degradation/ } \\
\text { FPase effect/ }\end{array}$ \\
\hline 1. & KLCD01 & 16 & 5 & 3.20 & + \\
\hline 2. & KLCD02 & 8 & 3 & 2.66 & - \\
\hline 3. & KLCD03 & 6 & 3 & 2.00 & \\
\hline 4. & KLCD04 & 17 & 7 & 2.42 & + \\
\hline 5. & KLCD05 & 9 & 5 & 1.80 & - \\
\hline 6. & KLCD06 & 7 & 6 & 1.166 & - \\
\hline 7. & KLCD07 & 7 & 4 & 1.75 & - \\
\hline 8. & KLCD08 & 26 & 6 & 5.770 & + \\
\hline 9. & KLCD09 & 14 & 5 & 5.222 & + \\
\hline 10. & KLCD10 & 5 & 3 & 1.66 & - \\
\hline 11. & KLCD11 & 8 & 5 & 1.60 & - \\
\hline 12. & KLCD12 & 19 & 7 & 2.916 & + \\
\hline 13. & KLCD13 & 7 & 3 & 2.33 & - \\
\hline 14. & KLCD14 & 8 & 5 & 1.66 & - \\
\hline 15. & KLCD15 & 20 & 10 & 3.500 & + \\
\hline 16. & KLCD16 & 6 & 4 & 1.5 & - \\
\hline 17. & KLCD17 & 8 & 5 & 1.60 & - \\
\hline 18. & KLCD18 & 15 & 8 & 2.727 & + \\
\hline 19. & KLCD19 & 10 & 10 & 2.333 & + \\
\hline 20. & KLCD20 & 9 & 4 & 2.25 & - \\
\hline
\end{tabular}

Measurement of clear zone diameter, colony diameter and hydrolytic value is based on CMC. 
eight isolates (KLCD01, KLCD04, KLCD09, KLCD12, KLCD18 and KLCD18) were able to degrade filter paper which was seen as decomposed filter paper forming a turbid solution in the test tube. The isolates were selected for further analysis. The result of filter paper degradation test indicated that not all bacterial isolate which shows hydrolytic effect on CMC are able to digest cellulose in the filter paper. Filter paper is made up of solid compact cellulose unlike $\mathrm{CMC}$ in which cellulose is present in a dissolved fine powder form. Hence, bacterial isolate which can degrade filter paper were considered to have more cellulolytic effect. Egwuatu et al, used filter paper degradation test for isolation of cellulose degrading bacteria from the Guts of Coptotermes formosanus ${ }^{15}$.

A diameter of clear zone, colony diameter, hydrolytic values and filter paper degradation effect of selected isolates is indicated in table 1.

Diameter of clear zone on CMC agar ranged from $25 \mathrm{~mm}$ to $34 \mathrm{~mm}$. highest diameter of clear zone was seen in KLCD1 and clear zone diameter was lowest in KLCD04. Highest hydrolytic zone was seen in KLCD8 and the lowest value was seen in KLCD12 and KLCD9. The current study showed that there is a positive correlation between hydrolytic value and filter paper degradation effect of the isolates. In the isolates with higher hydrolytic value on CMC, filter paper degradation effect is positive and vice versa. Similarly bacterial isolate having greater clear zone diameter on $\mathrm{CMC}$ were able to degrade filter paper. Hence in the present study it can be concluded that the greater clear zone diameter, the more cellulolytic potential. However Yan-Ling L. et al reported that diameter of clear zone and FPase activity is not directly related to enzyme activity ${ }^{24}$.

\section{Morphological and Biochemical characterization} Morphological analysis was done based on gram staining method. Gram staining and microscopic examination showed that the isolated strain KLCD08 was gram negative short rod (cocco-bacillus) and the remaining 7 isolated strains (KLCD01, KLCD09, KLCD1, KLCD2, KLCD3 and KLCD12) found to be gram-positive rod shape bacteria. Biochemical tests showed that, five isolates belong to bacillus species, two isolates fibrobacter and one was identified as Enterobacter species. The result of morphological and biochemical tests is indicated in table 2 below.

Biochemical tests showed that, five isolates belong to Bacillus species, two isolates fibrobacter and one was identified as Enterobacter

Table 2. Biochemical and morphological characteristics of selected cellulose degrading bacteria

\begin{tabular}{|c|c|c|c|c|c|c|c|c|c|c|c|c|}
\hline No. & $\begin{array}{l}\text { Isolate } \\
\text { ID }\end{array}$ & Mor & $\begin{array}{l}\text { Gram- } \\
\text { stain }\end{array}$ & $\mathrm{MT}$ & VP & IT & $\mathrm{CT}$ & $\mathrm{MR}$ & $\mathrm{CT}$ & $\mathrm{FR}$ & $\mathrm{H} 2$ & Identification \\
\hline 1. & KLCD01 & Rod & + & - & + & - & + & - & + & + & + & $\begin{array}{l}\text { Bacteriodes } \\
\text { Species }\end{array}$ \\
\hline 2. & KLCD04 & Rod & + & - & + & + & - & + & + & + & - & $\begin{array}{l}\text { Bacillus } \\
\text { Species }\end{array}$ \\
\hline 3. & KLCD08 & $\begin{array}{l}\text { Cocco- } \\
\text { baccillus }\end{array}$ & - & + & + & + & - & + & + & + & - & $\begin{array}{c}\text { Enterobacter } \\
\text { Species }\end{array}$ \\
\hline 4. & KLCD09 & Rod & + & - & + & - & + & - & + & + & + & $\begin{array}{l}\text { Bacteriodes } \\
\text { Species }\end{array}$ \\
\hline 5. & KLCD12 & Rod & + & - & + & + & - & + & + & + & - & $\begin{array}{l}\text { Bacillus } \\
\text { Species }\end{array}$ \\
\hline 6. & KLCD15 & Rod & + & - & + & + & - & + & + & + & - & $\begin{array}{l}\text { Bacillus } \\
\text { Species }\end{array}$ \\
\hline 7. & KLCD18 & Rod & + & - & + & + & - & + & + & + & - & $\begin{array}{l}\text { Bacillus } \\
\text { Species }\end{array}$ \\
\hline 8. & KLCD19 & Rod & + & - & + & + & - & + & + & + & - & $\begin{array}{l}\text { Bacillus } \\
\text { Species }\end{array}$ \\
\hline
\end{tabular}

Mor- Morphology, MT-Motility, VP-Voges Proskauer test, IT-Indole Test, CT-Catalase Test, MRT-Methyle red test, CaT-Catalase Test, FR-Fermentation test, H2-Hydrogen production test. 
species. The result of biochemical test of cellulose degrading bacteria in sheep rumen indicated that, majority (62.5\%) of the isolates are Bacillus species. Previous studies also showed that most of cellulolytic bacteria belong to genus Bacillus. Mohammed and et al. reported that out of 20 cellulolytic bacterial isolates, ten belong to Bacillus species $^{4}$.

\section{Enzyme activity Assay}

Cellulase enzyme was extracted from was analyzed using DNS (3,5-dinitrosalicylic acid) method to determine the amount of reducing sugar liberated from the substrate (CMC). Enzymatic activity was described by amount of glucose (reducing sugar) produced from CMC (carboxyl methylcellulose) within one minute at standard condition. Enzyme activity analysis result is presented in Table 2 .

Based on the enzyme activity assay KLCD08 showed greater activity with value of $1.652 \mathrm{U} / \mathrm{ml}$ and KLCD19 showed lowest activity $(0.119 \mathrm{U} / \mathrm{ml})$. The enzymatic activity of cellulase produced by bacteria depends on the species. The result of enzyme activity showed almost similar value with cellulolytic bacteria isolated from natural reserves in with maximum activity was $2.08 \mathrm{U} / \mathrm{ml}$ as reported by Yan-Ling L. et al. ${ }^{24}$.

\section{Estimation of molecular weight of cellulase} enzyme

Molecular weight of cellulase enzyme extracted from KLCD08 was determined by SDSPAGE. By using other molecular markers the molecular weight was estimated to be $45.2 \mathrm{kDa}$ as shown in the figure below.

There was variation between the present result of the current study and the previous report by Richa G.et al in which molecular weight of cellulase was reported to be $32.5 \mathrm{kDa}^{17}$.

16srRNA analysis and molecular characterization potential cellulolytic bacteria

KLCD08 showed the maximum enzymatic activity and was selected for molecular characterization using 16srRNA gene sequencing. The 16srRNA sequence of KLCD08 was blasted against the sequence available in EZBloCloud data base. The matching result showed that, KLCD08 was $99.84 \%$ homology with Enterobacter cloacae subsp. Dissolvens. A 16srRNA gene sequence was deposited in NCBI GenBank with accession number of MN120893. The current study concluded that
Table 3. Cellulase enzyme activity of selected CDB isolated from sheep rumen

\begin{tabular}{lcc}
\hline No. & $\begin{array}{c}\text { Isolate } \\
\text { ID }\end{array}$ & $\begin{array}{c}\text { Enzyme activity } \\
\text { (IU/ml) }\end{array}$ \\
\hline 1. & KLCD01 & 0.986 \\
2. & KLCD04 & 0.831 \\
3. & KLCD08 & 1.652 \\
4. & KLCD09 & 0.633 \\
5. & KLCD12 & 0.974 \\
6. & KLCD15 & 0.225 \\
7. & KLCD18 & 0.199 \\
8. & KLCD19 & 0.119 \\
\hline
\end{tabular}

Enterobacter cloacae is one of potential cellulose degrading bacteria in sheep rumen. Previous study by Wenny N. et al showed that Enetobacter species isolated from cattle rumen was found to be cellulolytic ${ }^{23}$. The potential cellulolytic bacteria identified in the current study could be used for large scale production of cellulase enzyme through bio-processing technology to fulfil demand for cellulase enzyme. It can also be formulated as probiotics to be used in animal nutrition.

$66 \mathrm{kDa}$

$45 \mathrm{kDa}$

$20.1 \mathrm{kDa}$

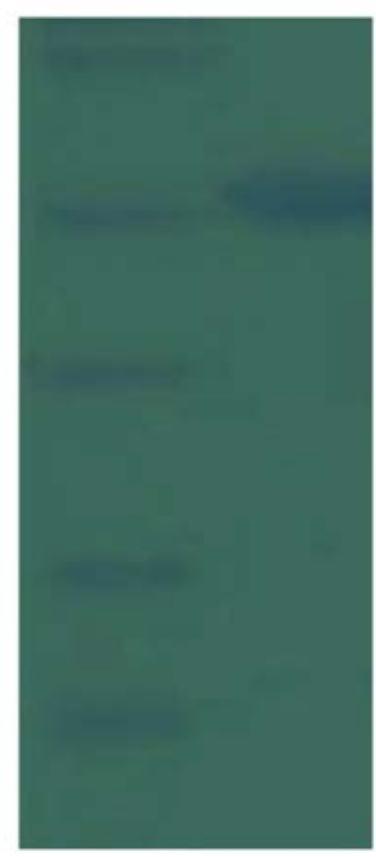

Fig. 1. SDS_PAGE of Cellulase enzyme extracted from $\mathrm{KLCD08}$ 


\section{DISCUSSION}

Cellulose degrading bacteria naturally present in gut of herbivores and termites as well as in organic waste materials. It is used to digest plant materials in by producing cellulase enzyme in herbivores and plant feeding insects. Cellulose degrading bacteria can be used for commercial production of cellulase enzyme in which the enzyme is extracted by the use of bio-processing technology from Cellulolytic bacteria ${ }^{1,2,3}$. Cellulolytic organisms can also be used as probiotics in animal nutrition.

In the present study, cellulose degrading bacteria was isolated from sheep rumen. Cellulose degrading bacteria was screened out by use of $\mathrm{CMC}$ agar. The isolate with significant cellulolytic effect on CMC agar was subjected to filter paper degradation test for further confirmation cellulolytic ability. Only Eight Bacterial isolate were able degrade filter paper. The result of filter paper degradation test indicated that not all bacterial isolate which shows hydrolytic effect on $\mathrm{CMC}$ are able to digest cellulose in the filter paper. Filter paper is made up of solid compact cellulose unlike $\mathrm{CMC}$ in which cellulose is present in a dissolved fine powder form. Hence, bacterial isolate which can degrade filter paper were considered to have more cellulolytic effect and selected for further analysis. Egwuatu et al., used filter paper degradation test for isolation of cellulose degrading bacteria from the Guts of Coptotermes formosanus. The current study showed that there is a positive correlation between hydrolytic value and filter paper degradation effect of the isolates. In the isolates with higher hydrolytic value on CMC, filter paper degradation effect is positive and vice versa. Similarly bacterial isolate having greater clear zone diameter on $\mathrm{CMC}$ were able to degrade filter paper. Hence in the present study it can be concluded that the greater clear zone diameter, the more cellulolytic potential. However Yan-Ling L. et al reported that diameter of clear zone and FPase activity is not directly related to enzyme activity ${ }^{24}$.

The screened cellulolytic isolates were identified by morphological and biochemical tests. Cellulase enzyme was extracted from selected bacterial isolated and cellulase activity assay was performed to identify the most potential cellulolytic bacteria. The enzymatic activity of cellulase produced by bacteria depends on the species. Based on the enzyme activity assay KLCD08 showed greater activity with value of $1.652 \mathrm{U} / \mathrm{ml}$ and KLCD19 showed lowest activity $(0.119 \mathrm{U} / \mathrm{ml})$. The result of enzyme activity showed almost similar value with cellulolytic bacteria isolated from natural reserves in with maximum activity was $2.08 \mathrm{U} / \mathrm{ml}$ as reported by Yan-Ling L. ${ }^{24}$.

The result of biochemical test of cellulose degrading bacteria in sheep rumen indicated that, majority (62.5\%) of the isolates are Bacillus species. Previous studies also showed that most of cellulolytic bacteria belong to genus Bacillus. Mohammed and et al reported that out of 20 cellulolytic bacterial isolates, ten belong to Bacillus species. Cellulase enzyme produced by most cellulolytic bacteria was partially purified by ammonium sulphate precipitation followed by dialysis. The molecular weight of partially purified enzyme was estimated by SDS-PAGE. Molecular weight of cellulase enzyme extracted from KLCD08 was determined by SDS-PAGE. By using other molecular markers the molecular weight was estimated to be $45.2 \mathrm{kDa}$. There was variation between the present result of the current study and the previous report by Richa G. et al. in which molecular weight of cellulase was reported to be $32.5 \mathrm{kDa}$. The bacterium with maximum cellulolytic was subjected to molecular characterization by 16srRNA gene sequencing. The matching result showed that, KLCD08 was $99.84 \%$ homology with Enterobacter cloacae subsp. Dissolvens. A 16srRNA gene sequence was deposited in GenBank with accession number of MN120893.

The current study concluded that Enterobacter cloacae is one of the most potential cellulose degrading bacteria in sheep rumen. Previous study by Wenny N. et al. showed that Enetobacter species isolated from cattle rumen was found to be cellulolytic. The potential cellulolytic bacteria identified in the current study could be used for large scale production of cellulase enzyme through bio-processing technology to fulfil demand for cellulase enzyme. It can also be formulated as probiotics to be used in animal nutrition. 


\section{ACKNOWLEDGEMENTS}

Authors would like to thank the HOD, Department of Biotechnology for providing laboratory facilities at KL University.

\section{CONFLICT OF INTEREST}

The authors declare that there is no conflict of interest.

\section{AUTHORS' CONTRIBUTION}

All authors listed have made a substantial, direct and intellectual contribution to the work, and approved it for publication.

\section{FUNDING}

This work was supported by Ministry of Science and Higher Education, Ethiopia.

\section{DATA AVAILABILITY}

All datasets generated or analyzed during this study are included in the manuscript.

\section{ETHICS STATEMENT}

This article does not contain any studies with human participants performed by any of the authors. There was no involvement of live animal in the study.

\section{REFERENCES}

1. Azhar A. Hussain, Mohamed S. Abdel-Salam, Hoda H. Abo-Ghalia, Wafaa K. Hegazy, Safa S. Hafez Optimization and molecular identification of novel cellulose degrading bacteria isolated from Egyptian environment, Journal of Genetic Engineering and Biotechnology, 2017; 15: 77-85. https://doi. org/10.1016/j.jgeb.2017.02.007

2. Egwuatu T.F. and Appeh O.G. Isolation and Characterization of Filter Paper Degrading Bacteria from the Guts of Coptotermes-formosanus, Journal of Bioremediation \& Biodegradation Egwuatu and Appeh, J. Bioremediat. Biodegrad., 2018; 9: 3. DOI: 10.4172/2155-6199.1000440. https://doi. org/10.4172/2155-6199.1000440

3. Gopinath S.M., Shareef I., Ashalatha Ranjit S. Isolation, screening and purification of cellulase from cellulase producing Klebsiella variicolaRBER3 (KF036184.1). Int. J. Sci. Res., 2012; 3:2319-7064.

4. H. S. Jun, M. Qi, J. K. Ha1 and C.W. Forsberg Fibrobacter succinogenes, a Dominant Fibrolytic Ruminal Bacterium: Transition to the Post Genomic Era, Department of Molecular and Cellular Biology, University of Guelph, Guelph, Ontario, N1G 2W1 Canada, Asian-Aust. J. Anim. Sci., 2007; 20(5): 802 810. https://doi.org/10.5713/ajas.2007.802

5. Haung X.P., Monk C. Purification and characterization of a cellulase from a newly isolated thermophilic aerobic bacterium Caldibacilluscellulovorans gen. nov. sp. World J. Microbiol. Biotechnol., 2004; 20: 85-92. https://doi.org/10.1023/B:WIBI.0000013316.12730. e7

6. Irfan M., Safdar A., Syed Q., Nadeem M. Isolation and screening of cellulolytic bacteria from soil and optimization of cellulase production and activity. Turk. J. Biochem., 2012; 37: 287-93.

7. Koike S. \& Kobayashi Y. Fibrolytic rumen bacteria: their ecology and functions. Asian-Aust. J. Anim. Sci., 2009; 22: 131-138. https://doi.org/10.5713/ajas.2009.r.01

8. Krause D.O., Denman S.E., Mackie R.I., Morrison M., Rae A.L., Attwood G.T. \& Mc Sweeney C.S. Opportunities to improve fiber degradation in the rumen: microbiology, ecology, and genomics. FEMS Microbiol. Rev., 2003; 27: 663-693. https://doi. org/10.1016/S0168-6445(03)00072-X

9. Larue R., Yu Z., Parisi V.A., Egan A.R. \& Morrison M. Novel microbial diversity adherent to plant biomass in the herbivore gastrointestinal tract, as revealed by ribosomal intergenic spacer analysis and rrs gene sequencing. Environ. Microbiol., 2005; 7: 530-543. https://doi.org/10.1111/j.1462-2920.2005.00721.x

10. Lee Y.J., Kim B.K., Lee B.H., Jo K.I., Lee N.K. Purification and characterization of cellulase produced by Bacillus amyloliquefaciensDL-3 utilizing rice hull. Coll. Nat. Resour. Life Sci., 2006; 840: 604-714.

11. Mahesh salunke Isolation and screening of cellulose degrading microorganisms from fecal matter of herbivores, International Journal of Scientific \& Engineering Research, 2012; 3(10): ISSN 2229-5518.

12. Maki M.L., Broere M., Leung K.T., Qin W. Characterization of some efficient cellulase producing bacteria isolated from paper mill sludges and organic fertilizers. Int. J. Biochem. Mol. Biol., 2011; 2(2):146-54.

13. Mohammed Rawway, Salah G. Ali and Ahmed S. Badaw. Isolation and Identification of Cellulose Degrading Bacteria from Different Sources at Assiut Governorate (Upper Egypt), Journal of Ecology of Health \& Environment, J. Eco. Heal. Env., 2018; 6(1): 15-24. https://doi.org/10.18576/jehe/060103

14. Pratima Gupta, Kalpana Samant, and Avinash Sahu. Isolation of Cellulose-Degrading Bacteria and Determination of Their Cellulolytic Potential, Department of Biotechnology, National Institute of Technology, India, 2011; 2012: Article ID 578925, 5 pages; https://doi.org/10.1155/2012/578925

15. Richa Gautam and Jitender Sharma Optimization, Purification of cellulase produced from Bacillus subtlissubspecies.Inaquosorum under solid state fermentation and its potential application in industry, International Journal of Science and Research, 2012; ISSN(online): 2319-7064.

16. Russell J.B., Muck R.E. \& Weimer P.J. Quantitative analysis of cellulose degradation and growth of cellulolytic bacteria in the rumen, FEMS Microbiol. Ecol., 2009; 67: 183-197. https://doi.org/10.1111/ j.1574-6941.2008.00633.x

17. Samsudin A.A., Wright A.D. \& A.I. Jassim R. Cellulolytic bacteria in the foregut of the dromedary camel (Camelus dromedarius). Appl. Environ. Microbiol., 
2012; 78: 8836-8839. https://doi.org/10.1128/ AEM.02420-12

18. Seo J.K., Park T.S., Kwon I.H., Piao M.Y., Lee C.H. \& Ha J.K. Characterization of cellulolytic and xylanolytic enzymes of Bacillus licheniformis JK7 isolated from the rumen of a native Korean goat. Asian-Aust. J. Anim. Sci., 2013; 26: 50-58. https://doi.org/10.5713/ ajas.2012.12506

19. Sonia Sethi, Aparna Datta, B. Lal Gupta, and Saksham Gupta Optimization of Cellulase Production from Bacteria Isolated from Soil, Hindawi Publishing Corporation, ISRN Biotechnology, 2013; 2013: Article ID 985685, 7pages. https://doi. org/10.5402/2013/985685

20. Tian Shuangqi, Wang Zhenyu, Fan Ziluan, Zuo Lili and Wang Jichan Determination methods of cellulase activity, School of Food Science and Engineering, Harbin Institute of Technology, Harbin 150090, 2011.

21. Toyoda A., lio W., Mitsumori M. \& Minato H. Isolation and identification of cellulose-binding proteins from sheep rumen contents. Appl. Environ. Microbiol., 2009;
75: 1667-1673. https://doi.org/10.1128/AEM.0183808

22. Wenny Novita Sari, Safika, Darmawi, and Yudha Fahrimal Isolation and identification of a cellulolytic Enterobacter from rumen of Aceh cattle, Vet. World, 2017; 10(12): 1515-1520, doi: 10.14202/ vetworld.2017.1515-1520. https://doi.org/10.14202/ vetworld.2017.1515-1520

23. Yan-Ling Liang, Zheng Zhang, Min Wu, Yuan $\mathrm{Wu}$, and Jia-Xun Feng Isolation, Screening, and Identification of Cellulolytic Bacteria from Natural Reserves in the Subtropical Region of China and Optimization of Cellulase Production by Paenibacillus terrae ME27-1 BioMed Research International, 2014; Article ID 512497, 13 pages, http://dx.doi. org/10.1155/2014/512497

24. Yin L.J., Huang P.S., Lin H.H. Isolation of cellulase producing bacteria and characterization of the cellulase from the isolated bacterium Cellulomonas sp. YJ5. J. Agric. Food Chem., 2010; 58: 9833-7. https:// doi.org/10.1021/jf1019104 